\title{
High blood glucose levels are associated with higher risk of colon cancer in men: a cohort study
}

\author{
Alexandra Vulcan ${ }^{1 *}$, Jonas Manjer ${ }^{2}$ and Bodil Ohlsson ${ }^{3}$
}

\begin{abstract}
Background: High levels of blood glucose are thought to be associated with colorectal cancer (CRC) and hyperinsulinemia, an interstage in the development of CRC. The purpose of this study was to examine associations between incident CRC and blood glucose; plasma insulin; and the homeostasis model assessment for insulin resistance (HOMA2-IR), respectively, and to determine whether these associations were dependent on sex and cancer site.

Methods: The Malmö Diet and Cancer cardiovascular cohort comprises 6103 individuals. During 81,781 person-years of follow-up, 145 cases of CRC were identified. The hazard ratio of measured blood glucose and plasma insulin and calculated HOMA2-IR were estimated with Cox proportional hazard regression.

Results: An association was found between high levels of blood glucose and risk of CRC (HR: 1.72 for the highest compared with the lowest quartile; $95 \% \mathrm{Cl}: 1.05,2.84 ; \mathrm{p}_{\text {trend }}=0.044$ ), and colon cancer (HR: 1.70 for the highest compared with the lowest quartile; $95 \% \mathrm{Cl}: 0.87,3.33 ; p_{\text {trend }}=0.032$ ). In men, an association was found between blood glucose and CRC (HR: 2.80 for the highest compared with the lowest quartile; 95\% Cl: 1.37, 5.70; $p_{\text {trend }}=0.001$ ), and colon cancer (HR: 4.48 for the highest compared with the lowest quartile; $95 \% \mathrm{Cl}: 1.27,15.84 ; \mathrm{p}_{\text {trend }}=0.007$ ), but this was not found in women. No associations between plasma insulin, or HOMA2-IR, and CRC, were found.

Conclusion: High levels of blood glucose in men are associated with risk of colon cancer. The findings contribute to facilitating to identify those most in need of prevention and screening.

Keywords: Blood glucose, Colorectal cancer (CRC), Homeostasis model assessment of insulin resistance (HOMA2-IR), Malmö diet and cancer study, Plasma insulin, Sex
\end{abstract}

\section{Background}

Colorectal cancer $(\mathrm{CRC})$ is one of the most common cancer forms in the Western world [1]. The increased incidence of CRC is associated with the increased incidence of lifestyle-related diseases, e.g., metabolic syndrome, overweight, obesity, and type 2 diabetes [2-4].

The latter diseases are characterized by hyperglycaemia, hyperinsulinemia, and insulin resistance [5]. The interaction between these diseases and CRC is being discussed, and molecular and etiological mechanisms are being sought. Hyperglycaemia might be associated with CRC [6], and the association may differ depending on different cancer sites

* Correspondence: alexandra.vulcan@med.lu.se

${ }^{1}$ Lund University, Skåne University Hospital, Department of Clinical Sciences, Division of Internal Medicine, Jan Waldenströms gata 14, 20502 Malmö, Sweden

Full list of author information is available at the end of the article and sex [4, 7]. Involvement of reactive oxygen species (ROS) and the accumulation of advanced glycation end products (AGE) are hypothesized to stimulate carcinogenic pathways [8-10]. Other proposals are that hyperinsulinemia drives the carcinogenic process through influence on the growth of cancer cells, stimulation of proliferation, decrease of apoptosis, and promotion of intestinal carcinogenesis [11]. Another hypothesis is that insulin resistance is responsible for the increased cancer risk. Although several studies have been conducted in the field, most of them have been case-control studies, and there has been discussion of whether further cohort studies are warranted [7].

\section{Method}

The primary aim of this study was to examine the associations between incident CRC and blood glucose levels; 
plasma insulin levels; and homeostasis model assessment for insulin resistance (HOMA2-IR), respectively, and incident CRC. The secondary aim was to study whether the associations were dependent on sex and cancer site.

The study was approved by the Regional Ethical Review Board in Lund (50-91, 2013/804).

\section{Study population}

The Malmö Diet and Cancer study (MDCS) is a large population-based study, conducted in the period 19911996 in Malmö, where all men and women, born between 1923 and 1950, were invited to participate. Altogether, 28,098 participants completed the baseline examinations after having given their written informed consent. The method of MDCS has previously been described by Manjer et al. [12]. The Malmö Diet and Cancer cardiovascular cohort (MDC-CC) comprises 6103 individuals randomly selected from MDCS. Out of the 6103 participants in MDC-CC, 5540 individuals accepted and were rescheduled for blood sampling. 396 individuals did not leave a blood glucose and plasma insulin sample and were therefore excluded from the present study, leaving 5144 individuals (2117 men). From the remaining individuals, prevalent diabetes was found in 219 individuals (123 men), and prevalent CRC in 14 individuals ( 2 men), at baseline, all of whom were also excluded from the study, leaving 4910 individuals (1992 men).

\section{Cases of CRC}

In the study, 145 cases of CRC (71 men) were identified from the Swedish Cancer Registry, of which 81 cases were colon cancer (37 men) and 64 were rectal cancer (34 men), during 81,781 person-years of follow-up. Follow-up time was defined as the time from the date of enrolment until the date of CRC diagnosis, death, migration or end of follow-up (31 December 2010), whichever came first. The mean follow-up was $16.7 \pm 3.7$ years.

\section{Plasma insulin, blood glucose and insulin resistance}

In the MDC-CC all the blood and plasma samples were collected at the MDC-CC baseline by a trained nurse in the morning after $12 \mathrm{~h}$ of fasting, and plasma was separated and immediately frozen at $-20{ }^{\circ} \mathrm{C}$ until analysed. Analyses were performed according to the clinical routines of the Department of Clinical Chemistry. Blood glucose was analysed using a routine hexokinase method. Insulin levels were measured in $\mathrm{mIU} / \mathrm{ml}$ by a radioimmunoassay. The lowest limit for detection was $3 \mathrm{mlU} / \mathrm{ml}$.

HOMA2-IR was calculated with the use of a HOMA2-IR calculator [13]. In the analysis of HOMA2-IR, extreme values of blood glucose $(<3.5$ or $>25 \mathrm{mmol} / \mathrm{l})$ were excluded, as were extreme values of plasma insulin $(<3$ or $>57.5 \mathrm{mIU} /$ $\mathrm{ml}$ ), thus leaving 4451 individuals for analysis of HOMA2-
IR. From the remaining individuals 135 cases of CRC, 76 cases colon cancer, and 59 cases of rectal cancer were found.

\section{Other variables}

At MDCS baseline, age was obtained from personal identification numbers. Body Mass Index (BMI) was calculated from measured weight and length.

A self-administered structured questionnaire was used for the assessment of level of education, physical activity, alcohol consumption and smoking. The level of education was divided into four different categories: $\leq 8$ years; 9-10 years; 11-13 years of education; and university degree. The subjects were asked to estimate their physical activity in terms of how many minutes per week they spent on 17 different activities. The duration was multiplied with an activityspecific intensity coefficient and an overall leisure-time physical activity score was created [14]. Alcohol intake was divided into four categories: zero; $<15 \mathrm{~g} / \mathrm{d}$ for women and $<20 \mathrm{~g} / \mathrm{d}$ for men; $15-30 \mathrm{~g} / \mathrm{d}$ for women and 20-40 g/d for men; and $>30 \mathrm{~g} / \mathrm{d}$ for women and $>40 \mathrm{~g} / \mathrm{d}$ for men. Smokers were divided into three categories: current smokers; exsmokers; and non-smokers. Irregular smoking was counted as current smoking. The result was divided into quartiles.

Prevalent diabetes was determined by self-reported illness based on physician's diagnosis or treatment with anti-diabetes medicine, or information from medical data registries indicating a date of diagnosis before inclusion in the MDC-CC. Incident diabetes diagnosis was obtained either from the Regional Diabetes 2000 register of Scania, the Malmö HbA1C register or the Swedish National Diabetes Register until 31st of December 2010. In the MDC-CC, 716 incident cases of diabetes (350 men) were found. In those with incident diabetes, 31 cases of incident CRC (22 men) were found.

\section{Statistics}

The SPSS statistics (version 23; IBM Corporation, Armonk, NY, USA) was used for all statistical analyses.

Chi-square test was used when examining baseline categorical characteristics, and T-test when examining baseline continuous characteristics, in the cases and the non-cases.

The Cox proportional hazard regression model was used when estimating hazard ratios (HR) of incident CRC, colon cancer, and rectal cancer, depending on quartiles of blood glucose, plasma insulin and HOMA2-IR. The proportionality assumption was tested for all the adjustment factors with a Kaplan-Maier curve before analysis. Two models are presented: an unadjusted model, and a full model. The full model was adjusted for the background variables indicating a difference between the cases and the non-cases $(p<0.2)$, i.e. age, sex (when appropriate), BMI, and smoking status. 
A test for interaction between sex and blood glucose; plasma insulin levels; and HOMA2-IR, respectively, with regard to CRC incidence was performed by adding a multiplicative variable (i.e. sex $\times$ blood glucose-/insulin-/HOMA2-IR quartiles (treated as continuous variables)) to the full model. If a significant interaction was found, subgroup analysis based on sex was performed.

In the sensitivity analysis, we excluded individuals with incident diabetes, and apart from that we made one additional model, full model glucose/insulin. The full model insulin was only used when estimating HR for quartiles of glucose and was adjusted for age, sex, BMI, smoking status, and insulin. The full model glucose was only used when estimating HR for quartiles of insulin and adjusted for age, sex, BMI, smoking status, and glucose. In addition, we excluded individuals with CRC diagnosis within two years of inclusion.

All tests were two-sided and statistical significance was assumed at $p<0.05$.

\section{Results}

Compared with the non-cases, the cases were older (Table 1), had larger waist circumference $(86.9 \pm 13.5 \mathrm{~cm}$ and $83.2 \pm 12.6 \mathrm{~cm}$, respectively, $p=0.019)$, and higher plasma insulin levels $(9.6 \pm 18.9 \mathrm{mIU} / \mathrm{ml}$ and $7.7 \pm 7.1$ $\mathrm{mIU} / \mathrm{ml}$, respectively, $p=0.012$ ) at inclusion. More of the cases than non-cases developed diabetes during the follow-up (21.4\% and 14.6\%, respectively).

Blood glucose levels and colorectal, colon, or rectal cancer An association between high levels of blood glucose and risk of CRC and colon cancer was found (HR: 1.72 for the highest compared with the lowest quartile; 95\% CI: 1.05, 2.84, $\mathrm{p}$ for trend $=0.044$ ) and (HR: 1.70 for the highest compared with the lowest quartile; $95 \% \mathrm{CI}$ : $0.87,3.33$, p for trend $=0.032$ ) (Table 2 ), respectively. With regard to blood glucose levels, an interaction between sex was found in CRC $(p=0.013)$ and in colon cancer $(p=0.032)$, but not in rectal cancer $(p=0.130)$. A significant association between high levels of blood glucose and CRC was found in men (HR: 2.80 for the highest compared with the lowest quartile; 95\% CI: 1.37, 5.70; p for trend $=0.001$ ), but not in women (HR: 1.02 for the highest compared with the lowest quartile; 95\% CI: 0.53, 1.95; p for trend = 0.739) (Table 3). Also, a significant association was found between high levels of blood glucose and colon cancer in men (HR: 4.23 for the highest compared with the lowest quartile; 95\% CI: 1.46, 13.44; p for trend $=0.002$ ), but not in women (HR: 1.01 for the highest compared with the lowest quartile; 95\% CI: 0.44, 2.34; p for trend $=0.878$ ) (Table 4).

Plasma insulin levels and colorectal, colon, or rectal cancer No significant associations were found between plasma insulin levels and CRC, colon, or rectal cancer (Table 2).
Table 1 Baseline characteristics of cases and non-cases in the Malmö Diet and Cancer Study cardiovascular cohort

\begin{tabular}{|c|c|c|c|}
\hline & $\begin{array}{l}\text { Cases } \\
n=145(\%)\end{array}$ & $\begin{array}{l}\text { Non-cases } \\
n=4765(\%)\end{array}$ & $p$-value \\
\hline Sex & & & 0.037 \\
\hline - Men & $71(49.0)$ & $1921(40.1)$ & \\
\hline - Women & $74(51.0)$ & $2844(59.9)$ & \\
\hline Age (years) & $61.3 \pm 7.0$ & $57.4 \pm 5.9$ & $<0.001$ \\
\hline Age quartiles & & & $<0.001$ \\
\hline $45.8-52.4$ years & $22(15.2)$ & $1205(25.3)$ & \\
\hline $52.4-57.8$ years & $26(17.9)$ & $1202(25.2)$ & \\
\hline $57.8-62.7$ years & $34(23.4)$ & $1194(25.1)$ & \\
\hline $62.7-68.1$ years & $63(43.5)$ & $1164(24.4)$ & \\
\hline Body Mass Index $\left(\mathrm{kg} / \mathrm{m}^{2}\right)$ & $26.2 \pm 3.9$ & $25.6 \pm 3.9$ & 0.032 \\
\hline Body Mass Index $\leq 25 \mathrm{~kg} / \mathrm{m}^{2}>$ & & & 0.155 \\
\hline$-\leq 25 \mathrm{~kg} / \mathrm{m}^{2}$ & $63(43.4)$ & $2356(49.4)$ & \\
\hline$->25 \mathrm{~kg} / \mathrm{m}^{2}$ & $82(56.6)$ & $2409(50.6)$ & \\
\hline Education & & & 0.732 \\
\hline - > 10 years & $42(29.0)$ & $1335(28.0)$ & \\
\hline$-\leq 10$ years & $103(71.0)$ & $3425(71.9)$ & \\
\hline - Missing & $0(0)$ & $5(0.1)$ & \\
\hline Physical activity & & & 0.439 \\
\hline$-\mathrm{High}^{\mathrm{c}}$ & $38(27.3)$ & $1182(24.5)$ & \\
\hline - Lower & $105(71.3)$ & $3555(74,9)$ & \\
\hline - Missing & $2(1.4)$ & $28(0.6)$ & \\
\hline Alcohol intake & & & 0.832 \\
\hline - Zero & $26(17.9)$ & $742(15.6)$ & \\
\hline $\begin{array}{l}-<15 \mathrm{~g} / \mathrm{d} \text { for women and } \\
<20 \mathrm{~g} / \mathrm{d} \text { for men }\end{array}$ & $91(62.8)$ & $3088(64.8)$ & \\
\hline $\begin{array}{l}-15-30 \mathrm{~g} / \mathrm{d} \text { for women and } \\
20-40 \mathrm{~g} / \mathrm{d} \text { for men }\end{array}$ & $21(14.5)$ & $757(15.9)$ & \\
\hline $\begin{array}{l}->30 \mathrm{~g} / \mathrm{d} \text { for women and } \\
>40 \mathrm{~g} / \mathrm{d} \text { for men }\end{array}$ & $7(4.8)$ & 173 (3.6) & \\
\hline - Missing & $0(0)$ & $5(0.1)$ & \\
\hline Smoking & & & 0.023 \\
\hline - Current & 31 (21.4) & 1307 (27.4) & \\
\hline - Ex & $65(44.8)$ & 1556 (32.7) & \\
\hline - Never & 49 (33.8) & 1900 (39.9) & \\
\hline - Missing & $0(0)$ & $2(0.04)$ & \\
\hline
\end{tabular}

${ }^{a}$ Calculated with Chi-square test for categorical variables and with T-test for the continuous variables

Physical activity was defined as high when in the highest quartile of the whole group, and lower when in the three lower quartiles [14]

Values are number of individuals and percentage or mean and standard deviation. $p<0.05$ was considered statistically significant

No interaction between sex and plasma insulin levels was found in CRC $(p=0.142)$, colon cancer $(p=0.358)$, or in rectal cancer $(p=0.280)$. 


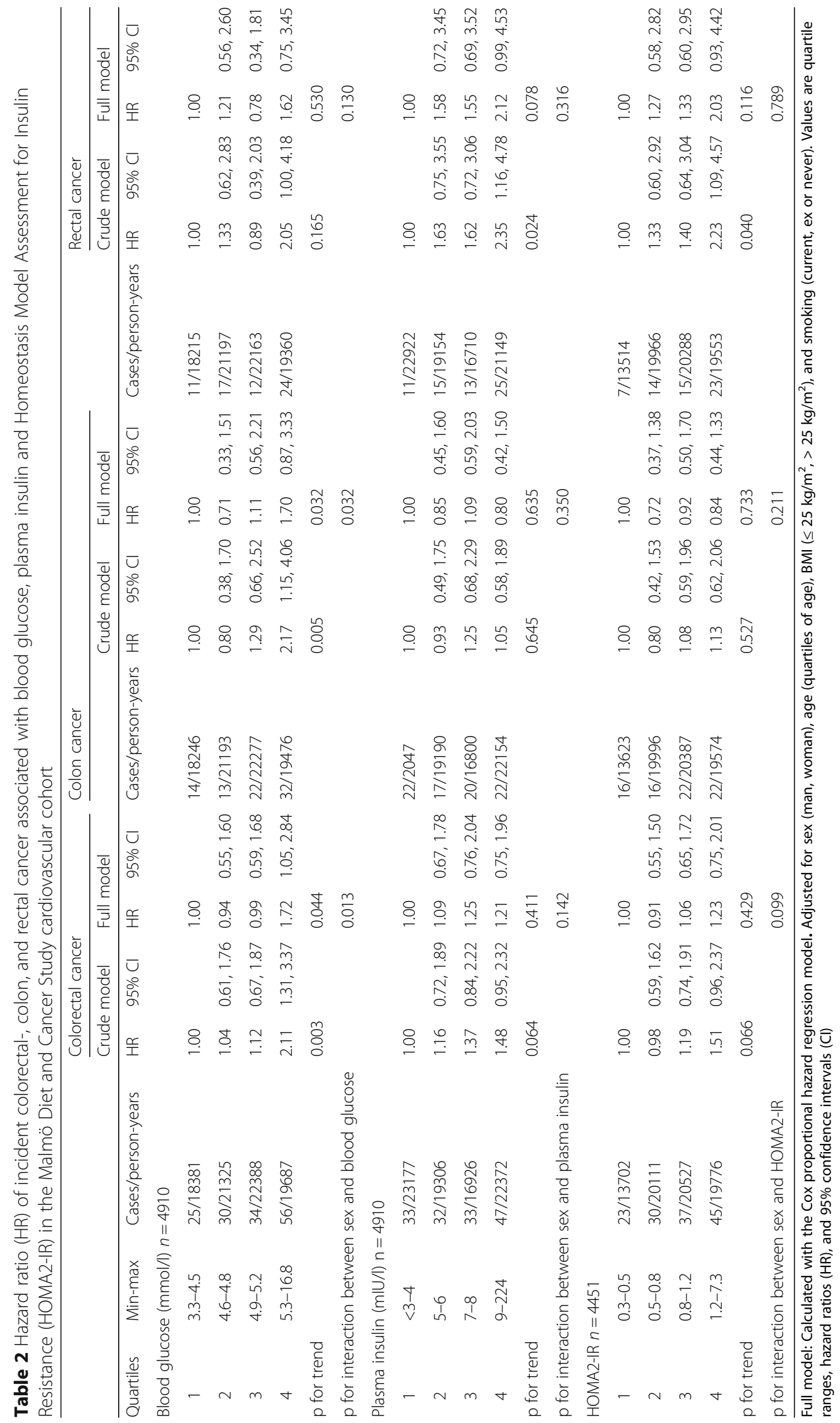


Table 3 Hazard ratio (HR) of incident colorectal- and colon cancer associated with blood glucose for men and women in the Malmö Diet and Cancer Study cardiovascular cohort

\begin{tabular}{|c|c|c|c|c|c|c|c|c|c|c|c|}
\hline \multirow[b]{3}{*}{ Quartiles of glucose } & \multirow[b]{3}{*}{ Min-max (mIU/l) } & \multicolumn{5}{|c|}{$\begin{array}{l}\text { Colorectal cancer } \\
\mathrm{n}_{\text {men }}=1992 \mathrm{n}_{\text {women }}=2981\end{array}$} & \multicolumn{5}{|c|}{$\begin{array}{l}\text { Colon cancer } \\
\mathrm{n}_{\text {men }}=1958 \mathrm{n}_{\text {women }}=2888\end{array}$} \\
\hline & & \multirow[b]{2}{*}{ Cases/person-years } & \multicolumn{2}{|c|}{ Crude model } & \multicolumn{2}{|c|}{ Full model } & \multirow[b]{2}{*}{ Cases/person-years } & \multicolumn{2}{|c|}{ Crude model } & \multicolumn{2}{|c|}{ Full model } \\
\hline & & & $\overline{\mathrm{HR}}$ & $95 \% \mathrm{Cl}$ & $\overline{\mathrm{HR}}$ & $95 \% \mathrm{Cl}$ & & $\overline{\mathrm{HR}}$ & $95 \% \mathrm{Cl}$ & $\overline{\mathrm{HR}}$ & $95 \% \mathrm{C}$ \\
\hline \multicolumn{12}{|l|}{ Men } \\
\hline 1 & $3.3-4.5$ & $5 / 4400$ & 1.00 & & 1.00 & & $2 / 4358$ & 1.00 & & 1.00 & \\
\hline 2 & $4.6-4.8$ & 10/7276 & 1.28 & $\begin{array}{l}0.57 \\
2.90\end{array}$ & 1.25 & $\begin{array}{l}0.55 \\
2.85\end{array}$ & $4 / 7216$ & 2.05 & $\begin{array}{l}0.50 \\
7.01\end{array}$ & 1.95 & $\begin{array}{l}0.57 \\
6.70\end{array}$ \\
\hline 3 & $4.9-5.2$ & $16 / 9835$ & 2.10 & $\begin{array}{l}0.99 \\
4.45\end{array}$ & 2.03 & $\begin{array}{l}0.95 \\
4.32\end{array}$ & 9/9767 & 2.28 & $\begin{array}{l}0.67 \\
7.79\end{array}$ & $2-08$ & $\begin{array}{l}0.60 \\
7.17\end{array}$ \\
\hline 4 & $5.3-16.8$ & $40 / 10853$ & 3.08 & $\begin{array}{l}1.54 \\
6.15\end{array}$ & 2.80 & $\begin{array}{l}1.37 \\
5.70\end{array}$ & 22/19679 & 5.40 & $\begin{array}{l}1.84 \\
15.87\end{array}$ & 4.23 & $\begin{array}{l}1.46 \\
13.44\end{array}$ \\
\hline$p$ for trend & & & $<0.001$ & & 0.001 & & & 0.001 & & 0.002 & \\
\hline \multicolumn{12}{|l|}{ Women } \\
\hline 1 & $3.4-4.5$ & 20/13981 & 1.00 & & 1.00 & & $12 / 13888$ & 1.00 & & 1.00 & \\
\hline 2 & $4.6-4.8$ & $20 / 14048$ & 1.24 & $\begin{array}{l}0.64 \\
2.38\end{array}$ & 1.21 & $\begin{array}{l}0.62 \\
2.34\end{array}$ & 9/13977 & 0.77 & $\begin{array}{l}0.29 \\
2.05\end{array}$ & 0.73 & $\begin{array}{l}0.27 \\
1.96\end{array}$ \\
\hline 3 & $4.9-5.2$ & $18 / 12553$ & 0.89 & $\begin{array}{l}0.47 \\
1.66\end{array}$ & 0.82 & $\begin{array}{l}0.44 \\
1.55\end{array}$ & $13 / 12510$ & 1.08 & $\begin{array}{l}0.50 \\
2.34\end{array}$ & 0.96 & $\begin{array}{l}0.45 \\
2.09\end{array}$ \\
\hline \multirow[t]{2}{*}{4} & $5.3-12.2$ & $16 / 8834$ & 1.16 & $\begin{array}{l}0.62 \\
2.17\end{array}$ & 1.02 & $\begin{array}{l}0.53 \\
1.95\end{array}$ & 10/8797 & 1.22 & $\begin{array}{l}0.54 \\
2.71\end{array}$ & 1.01 & $\begin{array}{l}0.44 \\
2.34\end{array}$ \\
\hline & & & 0.908 & & 0.739 & & & 0.562 & & 0.878 & \\
\hline
\end{tabular}

Full model: Calculated with the Cox proportional hazard regression model. Adjusted for age (quartiles of age), BMl ( $\leq 25 \mathrm{~kg} / \mathrm{m}^{2}$, $\left.>25 \mathrm{~kg} / \mathrm{m}^{2}\right)$, and smoking (current, ex or never) Values are quartile ranges, hazard ratios (HR), and $95 \%$ confidence intervals $(\mathrm{Cl})$

HOMA2-IR and colorectal, colon, or rectal cancer

No significant associations between HOMA2-IR and $\mathrm{CRC}$, colon, or rectal cancer were found in the full model (Table 2). There was a borderline interaction between sex and HOMA2-IR in CRC $(p=0.099)$, but not in colon cancer $(p=0.211)$, or rectal cancer $(p=0.789)$. The associations between HOMA2-IR and CRC did not reach statistical significance in men (HR: 1.62 for the highest compared with the lowest quartile; $95 \%$ CI: 0.81, 3.25; $\mathrm{p}$ for trend $=0.132$ ), or in women (HR: 0.77 for the

Table 4 Hazard ratio (HR) of incident colorectal cancer associated with Homeostasis Model Assessment for Insulin Resistance (HOMA2-IR) for men and women in the Malmö Diet and Cancer Study cardiovascular cohort

\begin{tabular}{|c|c|c|c|c|c|c|}
\hline \multirow[b]{2}{*}{ Quartiles of HOMA2-IR } & \multirow[b]{2}{*}{ Min-max (mIU/l) } & \multirow[b]{2}{*}{ Cases/person-years } & \multicolumn{2}{|c|}{ Unadjusted model } & \multicolumn{2}{|c|}{ Full model } \\
\hline & & & $\mathrm{HR}$ & $95 \% \mathrm{Cl}$ & $\mathrm{HR}$ & $95 \% \mathrm{Cl}$ \\
\hline \multicolumn{7}{|l|}{ Men $(n=1824)$} \\
\hline 1 & $0.35-0.63$ & $6 / 3938$ & 1.00 & & 1.00 & \\
\hline 2 & $0.64-0.90$ & 9/7615 & 0.66 & $0.30,1.47$ & 0.64 & $0.29,1.44$ \\
\hline 3 & $0.91-1.28$ & 19/8618 & 1.35 & $0.69,2.63$ & 1.29 & $0.65,2.56$ \\
\hline 4 & $1.29-6.85$ & $30 / 9434$ & 1.80 & $0.95,3.41$ & 1.62 & $0.81,3.25$ \\
\hline$p$ for trend & & & 0.042 & & 0.132 & \\
\hline \multicolumn{7}{|l|}{ Women $(n=2627)$} \\
\hline 1 & $0.34-0.51$ & $17 / 9764$ & 1.00 & & 1.00 & \\
\hline 2 & $0.52-0.77$ & $21 / 12496$ & 1.26 & $0.67,2.37$ & 1.11 & $0.59,2.09$ \\
\hline 3 & $0.78-1.06$ & 18/11908 & 1.15 & $0.60,2.18$ & 0.97 & $0.50,1.89$ \\
\hline 4 & $1.07-7.30$ & 15/10309 & 0.97 & $0.49,1.89$ & 0.77 & $0.37,1.59$ \\
\hline$p$ for trend & & & 0.760 & & 0.779 & \\
\hline
\end{tabular}

HR was calculated with the Cox proportional hazard regression model 
highest compared with the lowest quartile; 95\% CI: 0.37, 1.59; $\mathrm{p}$ for trend $=0.779)($ Table 4$)$.

\section{Sensitivity analysis}

After excluding those with incident diabetes, the association between blood glucose and CRC was no longer significant (HR: 1.74 for the highest compared with the lowest quartile; $95 \%$ CI: $1.00,3.07, \mathrm{p}$ for trend $=0.134$ ). The same was true for the association between blood glucose and colon cancer (HR: 1.71 for the highest compared with the lowest quartile; $95 \% \mathrm{CI}$ : $0.80,3.68$, p for trend $=0.128$ ). In men, the association between blood glucose and colon cancer had borderline significance (HR: 3.47 for the highest compared with the lowest quartile; $95 \% \mathrm{CI}$ : 0.88, 13.74, $\mathrm{p}$ for trend $=0.099$ ).

In excluding those with diagnosis of CRC within two years from inclusion in the study (13 individuals, where of eight were men), the association between blood glucose and CRC had borderline significance (HR: 1.71 for the highest compared with the lowest quartile; $95 \% \mathrm{CI}: 1.01$, 2.89 , $\mathrm{p}$ for trend $=0.090$ ), and the risk estimate for the association between blood glucose and rectal cancer in men increased (HR: 5.20 for the highest compared with the lowest quartile; $95 \% \mathrm{CI}: 1.47,18.43$, $\mathrm{p}$ for trend $=0.006$ ).

In additionally adjusting for insulin in the full model for glucose, neither the risk estimate, nor the significance substantially changed. Nor did they substantially change when additionally adjusting for glucose in the full model for insulin (data not shown).

\section{Discussion}

The results from the present study indicate that high levels of blood glucose are associated with risk of CRC, more specifically in men. No associations were found for insulin or HOMA2-IR and risk of CRC.

Our results are in agreement with other studies, which also found an association between high glucose levels and CRC, with significant associations in men, but not in women, and in colon cancer, but not in rectal cancer [7]. Glucose induces expressions of Amphiregulin, through transcriptional regulation of the MAX-like protein $X$ [15], suggesting that one part of the tumorigenesis in CRC might be glycolysis [16]. Furthermore, hyperglycaemia gives energy to malignant cells for their proliferation [16], and thus favours cancer growth and neoangiogenesis. Since there can be an insulinindependent glucose uptake in cancer cells, this may have an impact on the association between glucose, insulin and risk of CRC.

In hyperglycaemia, the cells' production of reactive oxygen intermediates increases, and is therefore speculated to be a part of the induction of apoptosis in endothelial cells [17]. Chronic inflammation, present for example during hyperglycaemia, leads to imbalance between production and restoration of ROS, leading to oxidative stress within the target tissue, which may damage DNA and reduce DNA repair [18].

Glucose and insulin levels are closely linked, which makes it difficult to separate the association, although they influence the cancer development through different pathways. Insulin stimulates the proliferation of cells partly through binding insulin to insulin- or insulin-like growth factor 1 (IGF-1) receptors, and partly through inhibition of IGF-binding proteins, thus increasing the availability for IGF-1 to bind to IGF-1 receptors [19]. Circulating IGF-1 is thought to increase the risk of CRC [20]. In a meta-analysis by Xu et al. [7], an association between plasma insulin levels and risk of CRC was found in case-cohort studies, but not in cohort studies, in line with the present cohort study.

Insulin resistance, hyperinsulinemia, and hyperglycaemia are important factors in metabolic syndrome. When insulin resistance develops in type 2 diabetes, the pancreatic insulin secretion is increased in compensation [21]. It is speculated that excess of insulin might enhance colonic epithelial activity and induce the formation of aberrant cryptic foci [22]. Insulin resistance affects the metabolic pathways, over-stimulates the mitogenic pathways and stimulates cell proliferation [23]. However, in the present study no association was found between HOMA2-IR and CRC, but this might be due to the small number of cases in the analysis.

In the present study, more of the cases than the noncases developed diabetes. They also had a larger waist circumference. Some research has suggested that the association between diabetes and CRC may not be causal; rather the two diseases just share the same preconditions, such as obesity [24]. This might be a reason why only high glucose levels, and not insulin and insulin resistance, show risk association. Metformin reduces insulin resistance and improves glycaemic control [25]. High intake of metformin seems to be protective against CRC [26]. The hypothesis is that metformin slows the progression and growth of the tumour [27]. In the present study, it was not possible to determine whether metformin was used between inclusion and the end of study, and this might have affected the results. However, in excluding incident diabetes in the sensitivity analysis, the effect on cancer development might have been avoided, but also excluding those with higher blood glucose, and decreasing the possible number of cases in the analysis.

As seen in our previous and present study on the MDCS, associations with CRC might not be straightforward, but may be dependent on sex and cancer site [28]. CRC may differ in nature depending on whether it is a distal or proximal CRC, with more micro instability in the distal CRC and more chromosomal instability in the proximal cancer [29]. Whether this difference can explain the variations in associations between rectal and 
colon cancer remains to be determined. There is a difference in the DNA methylation based on sex. An association between altered expressions and insulin secretion in the human pancreatic islet has been found, where women have a higher glucose-induced insulin secretion [30]. Oestrogen also plays an important role in the glucose metabolism in the body. Oestrogen facilitates the transport of glucose to the brain and promotes neural aerobic glycolysis [31]. In men, 5-DHEA, an adrenal steroid hormone which modulates glucose uptake, is more elevated than in women [32]. As there are differences in the glucose metabolism for men and women, high glucose levels may affect the risk differently, as seen in the present study.

The strength of the present research is that it is a cohort study with a long follow-up. A limitation of the study is the small number of cases, and it cannot be excluded that some of the stratified analyses may be underpowered. Taking family history of CRC or inflammatory bowel disease into account in our analyses would have been valuable, since they are contributing factors in the development of CRC [33], but information on these risk factors was missing, as was information on family history of diabetes and blood lipid profile. Even if adjustments for possible confounders and known risk factors were made, the occurrence of some residual confounding cannot be excluded.

\section{Conclusion}

High levels of blood glucose are associated with risk of CRC, mainly with colon cancer in men. The findings contribute to facilitating to identify those most in need of prevention and screening.

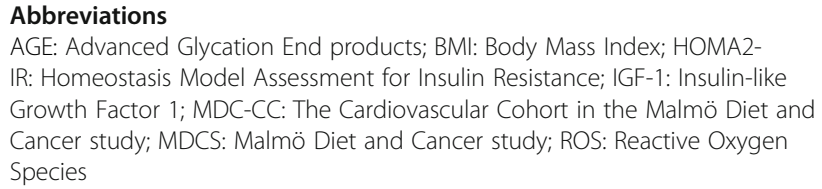

AGE: Advanced Glycation End products; BMI: Body Mass Index; HOMA2IR: Homeostasis Model Assessment for Insulin Resistance; IGF-1: Insulin-like Growth Factor 1; MDC-CC: The Cardiovascular Cohort in the Malmö Diet and Cancer study; MDCS: Malmö Diet and Cancer study; ROS: Reactive Oxygen Species

\section{Acknowledgments}

Professional writing service was provided by Anchor English.

\section{Funding}

This study was funded by grants from Development Foundation of Region Skåne, Direktör Albert Påhlsson's Foundation, the Malmö Hospital Foundation for Cancer Prevention and the South Region of healthcare. The funders had no role in the design, analysis or writing of this article.

\section{Availability of data and materials}

The data that supports the finding of this study are available from the Malmö Diet and Cancer Study, but restrictions apply to the availability of these data, which are used under license for the current study, and so are not publicly available. Data are however available from the authors upon reasonable request and with permission of the Malmö Diet and cancer study.

\section{Authors' contributions}

AV contributed to the study design, performed the data analysis and the interpretation of the results and wrote the manuscript. BO and JM contributed to the study design and interpretation of the results. BO financed the study. All authors contributed to the manuscript writing with constructive criticism.

\section{Ethics approval and consent to participate}

All procedures performed in the studies involving human participants were in accordance with the ethical standard of the ethical committee at Lund University (50-91, 2013/804) and with the 1964 Helsinki declaration and its later amendments or comparable ethical standards.

\section{Competing interest}

The authors declare that they have no competing interests.

\section{Consent for publication}

Not applicable.

\section{Publisher's Note}

Springer Nature remains neutral with regard to jurisdictional claims in published maps and institutional affiliations.

\section{Author details}

'Lund University, Skåne University Hospital, Department of Clinical Sciences, Division of Internal Medicine, Jan Waldenströms gata 14, 20502 Malmö, Sweden. ${ }^{2}$ Lund University, Skåne University Hospital, Department of Clinical Sciences, Division of Surgery, Inga Marie Nilssons gata 47, 20502 Malmö, Sweden. ${ }^{3}$ Lund University, Skåne University Hospital, Department of Clinical Sciences, Division of Internal Medicine, Jan Waldenströms gata 15, 20502 Malmö, Sweden.

Received: 12 April 2017 Accepted: 4 December 2017

Published online: 12 December 2017

\section{References}

1. Ferlay J, Steliarova-Foucher E, Lortet-Tieulent J, Rosso S, Coebergh JW, Comber H, Forman D, Bray F. Cancer incidence and mortality patterns in Europe: estimates for 40 countries in 2012. Eur J Cancer. 2013; doi:10.1016/j.ejca.2012.12.027

2. Ma Y, Yang Y, Wang F, Zhang P, Shi C, Zou Y, Qin H. Obesity and risk of colorectal cancer: a systematic review of prospective studies. PLoS One. 2013; doi:10.1371/journal.pone.0053916.

3. Kramer HU, Schottker B, Raum E. Brenner H (2012) type 2 diabetes mellitus and colorectal cancer: meta-analysis on sex-specific differences. Eur J Cancer. 2012; doi:10.1016/j.ejca.2011.07.010.

4. Yuhara H, Steinmaus C, Cohen SE, Corley DA, Tei Y. Buffler PA (2011) is diabetes mellitus an independent risk factor for colon cancer and rectal cancer? Am J Gastroenterol. 2011; https://doi.org/10.1038/ajg.2011.301.

5. Maitra A. Endocrine system. In: Kumar V, Abbas A, J. A, editors. Robbins Basic Pathology, 9th edition. Philadelphia, USA; Elsevier Saunders; 2013. p 715-763.

6. Shin HY, Jung KJ, Linton JA. Jee SH (2014) association between fasting serum glucose levels and incidence of colorectal cancer in Korean men: the Korean cancer prevention study-II. Metab Clin Exp. 2014; doi:10.1016/j.metabol.2014.07.006

7. Xu J, Ye Y, Wu H, Duerksen-Hughes P, Zhang H, Li P, Huang J, Yang J, Wu Y, Xia D. Association between markers of glucose metabolism and risk of colorectal cancer. BMJ Open. 2016; doi:10.1136/bmjopen-2016-011430.

8. Van Guilder GP, Hoetzer GL, Greiner JJ, Stauffer BL, Desouza CA. Influence of metabolic syndrome on biomarkers of oxidative stress and inflammation in obese adults. Obesity. 2006; doi:10.1038/oby.2006.248.

9. Wang L, Cai S, Teng Z, Zhao X, Chen X, Bai X. Insulin therapy contributes to the increased risk of colorectal cancer in diabetes patients: a meta-analysis. Diagn Pathol. 2013; doi:10.1186/1746-1596-8-180.

10. Lee $W$. The CEACAM1 expression is decreased in the liver of severely obese patients with or without diabetes. Diagn Pathol. 2011; doi:10.1186/1746-1596-6-40.

11. Giovannucci E. Insulin, insulin-like growth factors and colon cancer: a review of the evidence. The Journal of nutrition 2001; 131 Supplement 11:3109S-3120S.

12. Manjer J, Carlsson S, Elmstahl S, Gullberg B, Janzon L, Lindstrom M, Mattisson I, Berglund G. The Malmo diet and cancer study: representativity, cancer incidence and mortality in participants and non-participants. European journal of cancer prevention : the official journal of the European Cancer Prevention Organisation. 2001;10:489-99. 
13. The Oxford Centre for Diabetes, Endocinology, and Metabolism, Diabetes Trials Unit. The University of Oxford. 2016. https://www.dtu.ox.ac.uk/ homacalculator. Acessed 15 Nov 2016.

14. Li C, Aronsson CA, Hedblad B, Gullberg B, Wirfalt E, Berglund G. Ability of physical activity measurements to assess health-related risks. Eur J Clin Nutr. 2009; doi:0.1038/ejen.2009.69.

15. Nam SO, Yotsumoto F, Miyata K, Fukagawa S, Yamada H, Kuroki M. Miyamoto $S$ (2015) Warburg effect regulated by amphiregulin in the development of colorectal cancer. Cancer medicine. 2015; doi:10.1002/cam4.416.

16. Yeh CS, Wang JY, Chung FY, Lee SC, Huang MY, Kuo CW, Yang MJ, Lin SR. Significance of the glycolytic pathway and glycolysis related-genes in tumorigenesis of human colorectal cancers. Oncol Rep. 2008;19:81-91.

17. Du X, Stocklauser-Farber K, Rosen P. Generation of reactive oxygen intermediates, activation of NF-kappaB, and induction of apoptosis in human endothelial cells by glucose: role of nitric oxide synthase? Free Radic Biol Med. 1999;27:752-63.

18. Coussens LM, Werb Z. Inflammation and cancer. Nature. 2002; doi:10.1038/nature01322.

19. Sandhu MS, Dunger DB, Giovannucci EL. Insulin, insulin-like growth factor-I (IGF-I), IGF binding proteins, their biologic interactions, and colorectal cancer. J Natl Cancer Inst. 2002;94:972-80.

20. Chi F, Wu R, Zeng YC, Xing R, Liu Y. Circulation insulin-like growth factor peptides and colorectal cancer risk: an updated systematic review and metaanalysis. Mol Biol Rep. 2013; doi:10.1007/s11033-012-2432-z.

21. Akbaraly TN, Kumari M, Head J, Ritchie K, Ancelin ML, Tabak AG, Brunner E, Chaudieu I, Marmot MG, Ferrie JE, Shipley MJ, Kivimaki M. Glycemia, insulin resistance, insulin secretion, and risk of depressive symptoms in middle age. Diabetes Care. 2013; doi:10.2337/dc12-0239.

22. Ezuka A, Sakai E, Kawana K, Nagase H, Kakuta Y, Uchiyama S, Ohkubo H, Higurashi T, Nonaka T, Endo H, Takahashi H, Nakajima A. Association between factors associated with colorectal cancer and rectal aberrant crypt foci in humans. Oncol Lett. 2015; doi:10.3892/ol.2015.3763.

23. Cusi K, Maezono K, Osman A, Pendergrass M, Patti ME, Pratipanawatr T, DeFronzo RA, Kahn CR, Mandarino LJ. Insulin resistance differentially affects the PI 3-kinase- and MAP kinase-mediated signaling in human muscle. J Clin Invest. 2000; doi:10.1172/JCl7535.

24. Giovannucci E, Harlan DM, Archer MC, Bergenstal RM, Gapstur SM, Habel LA, Pollak M, Regensteiner JG, Yee D. Diabetes and cancer: a consensus report. Diabetes Care. 2010; https://doi.org/10.2337/dc10-0666.

25. Bordini HP, Kremer JL, Fagundes TR, Melo GP, Conchon-Costa I, da Silva SS, Cecchini AL, Panis C, Luiz RC. Protective effect of metformin in an aberrant crypt foci model induced by 1,2-dimethylhydrazine: modulation of oxidative stress and inflammatory process. Mol Carcinog. 2016; doi:10.1002/mc.22545.

26. Cardel M, Jensen SM, Pottegard A, Jorgensen TL, Hallas J. Long-term use of metformin and colorectal cancer risk in type II diabetics: a population-based case-control study. Cancer medicine. 2014; doi:10.1002/cam4.306.

27. Hosono K, Endo H, Takahashi H, Sugiyama M, Sakai E, Uchiyama T, Suzuki K, lida H, Sakamoto Y, Yoneda K, Koide T, Tokoro C, Abe Y, Inamori M, Nakagama H, Nakajima A. Metformin suppresses colorectal aberrant crypt foci in a short-term clinical trial. Cancer Prev Res. 2010; doi:10.1158/1940-6207.CAPR-10-0186.

28. Vulcan A, Brandstedt J, Manjer J, Jirstrom K, Ohlsson B, Ericson U. Fibre intake and incident colorectal cancer depending on fibre source, sex, tumour location and tumour, node, metastasis stage. Br J Nutr. 2015; doi:10.1017/S0007114515002743.

29. Lee GH, Malietzis G, Askari A, Bernardo D, Al-Hassi HO, Clark SK. Is rightsided colon cancer different to left-sided colorectal cancer? - a systematic review. European journal of surgical oncology : the journal of the European Society of Surgical Oncology and the British Association of Surgical Oncology. 2015; doi:10.1016/j.ejso.2014.11.001.

30. Hall E, Volkov P, Dayeh T, Esguerra JL, Salo S, Eliasson L, Ronn T, Bacos K, Ling C. Sex differences in the genome-wide DNA methylation pattern and impact on gene expression, microRNA levels and insulin secretion in human pancreatic islets. Genome Biol. 2014; doi:10.1186/s13059-014-0522-z.

31. Rettberg JR, Yao J, Brinton RD. Estrogen: a master regulator of bioenergetic systems in the brain and body. Front Neuroendocrinol. 2014; doi:10.1016/j.yfrne.2013.08.001.

32. Comitato R, Saba A, Turrini A, Arganini C, Virgili F. Sex hormones and macronutrient metabolism. Crit Rev Food Sci Nutr. 2015; doi:10.1080/10408398.2011.651177.

33. Butterworth AS, Higgins JP, Pharoah P. Relative and absolute risk of colorectal cancer for individuals with a family history: a meta-analysis. Eur J Cancer. 2006; doi:10.1016/j.ejca.2005.09.023.

\section{Submit your next manuscript to BioMed Central and we will help you at every step:}

- We accept pre-submission inquiries

- Our selector tool helps you to find the most relevant journal

- We provide round the clock customer support

- Convenient online submission

- Thorough peer review

- Inclusion in PubMed and all major indexing services

- Maximum visibility for your research

Submit your manuscript at www.biomedcentral.com/submit 